outset, Dr. Henderson stated that though the admission rate to his hospital for cases of mental disorder due to alcoholism has been reduced from one half to one third of what it was twenty to thirty years ago, much more could be accomplished by more intense propaganda, educational campaigns and all manner of social influences. It is, however, by the methods and technique of psychiatry that the causation of alcoholism can best be elucidated and the best modes of treatment devised. It is essential, he declared, that alcoholism should be regarded as an illness or disease and not as a crime or misdemeanour, as is still done even to-day by some medical practitioners. Dr. Henderson then discussed alcoholism as a cause of homicide, assault, sex offences with adults or children and suicide, as well as the effect of parental alcoholism on the ehildren and the relation of alcoholism to mental disease. In conclusion, he urged that the lunacy laws, which he said are archaic both in name and form, should be replaced by mental health laws applicable to all groups of nervous and mental disease.

\section{Co-operation in Bibliography}

THe movement for co-operation in bibliography has received an important impetus from the Bataafsche Petroleum Maatschappij. This company classifies, by means of the Decimal Classification, 150,000 references annually to literature in chemistry, physics, etc., and their applications. We learn from Dr. S. C. Bradford that, since March last, the firm has contributed copies of its non-secret references to the Science Library, for intercalation, with titles from other sources using the standard classification, in its Subject-Matter Index of $2 \frac{1}{2}$ million references to scientific papers. This valuable contribution exemplifies the new spirit of co-operation in bibliography, which is surely achieving the production of a complete index to the records of discovery and invention. It is interesting to note, also, that Dr. Maximilian Pflucke, the editor of the Chemisches Zentralblatt, is collaborating in the production of the German edition of the Decimal Classification.

\section{The Liverpool Biological Society}

THE fiftieth anniversary of the Liverpool Biological Society is an event of more than local import. ance in that the large amount of original work by its members has wide significance, particularly through the foundations laid by one of its most prominent leaders, the late Sir William Herdman. Founded in 1886, the Liverpool Biological Society has since worked in close association with the Department of Zoology of the University of Liverpool, the Lancashire Sea Fisheries Laboratory and the Liverpool Marine Biological Committee which was started as a section of it, but some years ago, on the origin of the Department and chair of oceanography at the University, was absorbed in that. The Trans. actions of the Society have been issued annually and contain a wealth of original papers. The Society has always had distinguished presidents, some prominent past names being Profs. W. Mitchell Banks, Sir
William Herdman, R. J. Harvey Gibson, Robert Newstead, P. G. H. Boswell, W. Dakin and J. Johnstone; the present holder of the office is Dr. R. J. Daniel. It was Sir William Herdman, in preWar days, who succeeded in interesting city businessmen in the Society's activities, thereby increasing its financial support and enabling it to build up a valuable library. In 1924, the Liverpool Heredity Society amalgamated with it, following which special attention was given to this side of biological study. Although the Society's membership was 130 ten years ago, it now musters only about sixty, chiefly connected with the University. With its annual meeting in October, it meets, usually, at the University, every month during winter, with occasional summer excursions.

\section{American Cultural Origins}

The latest addition to the excellent series of "Leaflets" describing the collections of the Field Museum of Natural History, Chicago ("Archaeology of South America". By Fric J. Thompson. Leaflet 33. Field Museum of Natural History, Chicago. Pp. 160, 12 pls., 18 text-figures and 1 map), is an introduction to, and description of, the cases in the museum covering the archæology of South America. An account of the culture of the separate and distinct geographical and cultural areas of the sub-continent is preceded, by way of introduction, by a concise review of current theory of American origins. The indigenous civilization of South America, when the pre-Inca and Inca peoples are taken into account, ranges from the greatest achievements in social organization and material development of the New World before Columbus to what is perhaps the most backward of any culture known among surviving primitive peoples-the culture of the Yahgans of Tierra del Fuego, a people who in their native state have not advanced so far as polishing stone.

THE Yahgans are taken, with reservations, as representing the culture of the earliest immigrants into the continent. The physical characters of the earlier arrivals probably were those of the Lagoa Santa skull type. Such innovations as basketry, bow and arrow and the domestic dog may, it is thought, have been brought in by the third wave of immigra. tion, broad-headed peoples, also coming from Asia. The turning point in cultural development is the introduction of agriculture. Mr. Thompson is inclined to the view, now current, that the origins of the advanced American eivilization must be sought in South rather than Central America; and he is disposed to hold that the domestication of plants, which took place about five to eight thousand years ago, began in eastern South America with the cultivation of manioc, rather than, as is generally assumed, in Central America with the development of maize from the wild grass Teocentli (Euchlaena mexicana). While $\mathrm{Mr}$. Thompson rejects so low an estimate as two thousand years as the period of man's existence on the continent, he does not consider that a higher antiquity than twenty thousand years is probable. 